\title{
The Nigerian Civil War: There Was No Justification
}

\section{Okoro Innocent Agwu}

Department of History, International Relations, Ebonyi State University, Abakaliki, Nigeria

\section{Email address:}

rev.okoroinnocent@hotmail.com

\section{To cite this article:}

Okoro Innocent Agwu. The Nigerian Civil War: There Was No Justification. Journal of Political Science and International Relations. Special Issue: Nigerian-Biafra War: Reinterrogating Indiscipline and Sabotage Among the Biafran Soldiers 1967 - 1970.

Vol. 3, No. 1, 2020, pp. 1-8.doi: 10.11648/j.jpsir.20200301.11

Received: November 28, 2019; Accepted: December 24, 2019; Published: January 7, 2020

\begin{abstract}
The war which was fought in Nigeria from August 1967 to January 1970 has generally been described as the most horrific experience in the African continent and has never been equated to any other war in the history of black African continent before or since then. The war later began to define several activities in Nigeria ranging from economy, social, to political life. Yet, the Actors in the war have never regretted for once, except as they carried their heads high to the boasting that they fought to get Nigeria united. Many questions have been asked by Nigerians within and abroad as to how honest this unity is, in view of the increase in corruption, ethnic agitations, terrorism, and several vices. Attempts have been made to study analytically, the civil war with the aid of mostly secondary sources and internet materials. The result of the analysis here brings us to the disappointing conclusion that the war itself was not necessary in view of the fact that several alternative ways for peaceful unity of Nigeria could have been adopted. The study concludes with the note that Nigeria needs to unite together and work on the various aspirations of her different ethnic groups as to be the great nation it was meant to be.
\end{abstract}

Keywords: Civil, War, Biafra, Justification, Nigeria

\section{Introduction}

The Nigerian civil war which is also called the NigeriaBiafra war or simply Biafran war as it is known and called in many parts of the world today has been described as the most horrifying in the history of black Africa. It started as a war of survival for both sides; although the description of survival applied more to the Biafrans than Nigerians due to various reasons. The Biafran people had the right to complain because they were massacred in the Northern part of Nigeria especially in their business places and offices. Gowon's statement in a state broadcast emphasized the imperative of this complaint when he lamented that:"I receive complaints on daily basis that the Easterners living in the North are being killed and molested and their property looted. It appears that it is going beyond reason and is now at a point of recklessness and irresponsibility" [1].

This was later confirmed by Ojukwu when he was granted an interview by Chibuikem [1]. Then at the declaration of secession of Biafra by the suffering Easterners arising from no commensurate protection by the then Federal Government demonstrated by Gowon's make-believe attendance of Aburi
Conference with his men, a full blown war was declared against the young state of Biafra by Nigeria. This was after some other failed strategies to humiliate them [2]. With time, the war became worse and assumed new dimensions when the new state of Biafra resisted the Nigerian forces and declared itself another African state [3]. It is necessary to study the Biafran war especially as some of the major Actors are still alive to respond more clearly from deeper perspectives previously unknown to us. The lessons of the horrific impacts of the war on the Nigerian soil, water and air during the first decade of Nigeria's independence remain of immense importance to us especially now. It is equally necessary to study and to know about the events which led to the war as well as efforts made to stop the fight both at the beginning and within the fighting time if any.

Most importantly, the war needs to be analyzed enough as to be sure that it was a necessary struggle or otherwise. As the Actors still claim that they fought Biafra to unite the nation Nigeria, we need to re-examine the claims very closely to justify them or otherwise learn to avoid unnecessary crises like that one in future. The present generation and indeed future generations have the right to know if the war declared on Biafra by Nigeria was the very 
last option or if there were alternatives. The paper is set to investigate how many round pegs were fixed in round holes before opting for war and genocidal activities against mostly the Igbo people.

\section{The Conceptual/Theoretical Framework}

\subsection{The Concept-Nigerian Civil War}

A 30 month war broke out between the then Eastern region of Nigeria and the rest of Nigeria from July 1967 to January 1970. This is the war which is presently referred to as the Nigerian civil war. The term naturally implies that the war occurred within a nation among brothers. Normally this was to be taken in the spirit and understanding of "no victor and no vanquished" statement of the then Federal Government administration of Gowon. The statement was contained in Gowon's national address after the official surrender of Biafra's leadership as the war formally ended, on the $15^{\text {th }}$ of January, 1970. But several years of neglect, careless looting, and outright marginalization of the former secessionist area by successive Nigerian leadership have passed. So Nigerians began to rethink on Gowon's "no victor, no vanquished" statement. That is why manyNigerian citizens within and outside the country freely refer to the same crises as Biafran war instead of merely calling it a "Civil War". This is evidently deduced from Aloko Adewale Peter's work as follows:

The Nigerian Civil War, also known as the NigerianBiafra War, 6 July, 1967 - 15 January 1970, was a political conflict caused by the attempted secession of the Southeastern province of Nigeria as the self-proclaimed Republic of Biafra. The conflict was as a result of economic, ethnic, cultural and religious tensions among the various peoples of Nigeria. The Nigerian government launched a "police action" to retake secessionist territory. The struggle began on $6^{\text {th }}$ July 1967 when Nigerian federal troops advanced in two columns into Biafra. The Nigerian army offensive was through the North of Biafra led by Col Shuwa and the local military units were formed as the $1^{\text {st }}$ Infantry Division. The Division was led mostly by Northern officers. After facing unexpectedly fierce resistance and high casualties, the right-hand Nigerian column advanced on the town of Nsukka which fell on 14 July, while the left-hand column made for Garkem which was captured on 12 July [4].

\subsection{The Concept-Biafra}

Biafra was the word adopted by the consultative council which included the representatives of the tribes that constituted the then Eastern region of Nigeria and which agreed to become a sovereign state of her own in May 1967. The meaning of Biafra is not too clear as it is neither an Igbo word nor of the other tribes- Anang, Ibibio, Effik, Ejagham, and the rest. The name might have been adopted from the
"Bite of Biafra" situated in the gulf within the Atlantic and found conspicuously in the map. It has probably been changed to gulf of Guinea after the war, and probably too, to erase the horror of Biafran war experience in the minds of all, as well as try to stop the oncoming generations from thinking Biafra. The Biafran nation as it were, had the Igbo as the dominant tribe- up to $70 \%$ [5]. Most of the Biafran Actors were therefore of the Igbos because the number of victims of the crises were equally of the Igbo mostly. This is why you will always hear the word "Ndi Igbo" meaning the Igbo people when you are reading of Biafra. Some authors consulted used the word "Ndi Igbo" while describing certain situations and experiences of the same war; and you will sometimes come across same word in this paper. It is in view of the above explanation that this paper shall use both Nigerian civil war and, the Biafran war interchangeably to refer to the same 30 months war of 1967 to 1970 .

\subsection{The Theoretical Framework}

Wars and other crises among men are mainly the results of disagreements and most times bothering on economic and social misplacements. Same applied to the Biafra war of 1967 to 1970 . Therefore, the best discussion of the Biafra war can be done using Social conflict theory (SCT) hence this paper is adopting SCT.

Assertions have been made toward the social conflict theory as we see in "Machiavelli's and Hobbs' thoughts concluding that the tendency towards conflicts is the basic element to human nature [6].

However, experience has shown that conflict and struggle can somehow promote human social existence by ensuring that the strongest of the species survive. The great Garman theorist and political activist Karl Marx who lived in 1818 to 1883 presents the root of this idea in several social conflict theories (SCT) [7].

The theory of social conflict seeks to answer such questions as: why do fists get clinched, even in the hearts? Why are societies in perpetual conflict? Why are the contending problems of the societies not solved at once? What are the major causes of conflicts?

Social conflict theory (SCT) sees society as a complex system characterized by inequalities and conflicts that generate social changes. The SCT is a Marxist based social theory which argues that individuals and groups within the society (social class) have differing amount of material and non material resources, technically put as the haves and havenots, and that the most powerful groups use their power to exploit the less powerful. Marx further made a critique on the broad social system by saying that the history of the existing society is the history of class struggle, free man and slave, patrician and plebeian, lord and serfs, guild master and journey man in a word, oppressor and the oppressed standing in constant opposition to one another carried on an uninterrupted now hidden, now open fight; a fight that each time ended either in revolutionary fight of society at large, or in the common ruin of the contending class [8]. Nevertheless, $\mathrm{SCT}$ can be found useful in all social issues like sports, 
politics, normal social engagements and society at large. SCT can be viewed from the prism of social inequality, favoritism in various aspects of social living and society through mediums of ethnicity, age, gender, race etc. And these factors influence wealth, schooling, power, and prestige. SCT paradigm views the patterns that benefit some people more than it would others due to their social status. Notable scholars of SCT are Karl Marx, Marx Weber, and Fredrik Engels among many others.

The views, ideas and aspirations on social conflict theory cannot be over emphasized, as it shows the dichotomy of class struggles resulting from the factors of economy based on the forces of production [9]. Taking it from there, we need to note that, the dichotomy discovered in the case of the then Eastern region of Nigeria and the other parts of the Federal government was mainly politics and religion [10].

\section{The Major Actors in the Crises: A Quick Review}

The major Actors of the Nigerian civil war were Yakubu Gowon the then Military Head of State of Nigeria, and Chukwuemeka Odumegwu Ojukwu the then Military Governor of the Eastern Region respectively. Many others like former two times president of Nigeria- Olusegun Obasanjo, Wole Soyinka, Philip Effiong, Emmanuel Ifeajuna, Kaduna Nzeogwu, Joseph Achuzie, Samuel Agbam, Emmanuel Nwobosi, Humphery Chukwuma, Timothy Onwuatuegwu, Ibrahim Badamasi Babangida, Muhamadu Buhari, AbulsalamiAbubarkar, and a host of others too numerous to mention, including several current players in the present generation of Nigeria leadership were very much involved. Our analysis will centre only on Gowon and Ojukwu- the two principal Actors.

\subsection{General Yakubu Gowon}

This great man was born to a Methodist Evangelist and farmer on October 19, 1934 in the Northern Nigeria. He had his Primary school in his village of birth and his Secondary school at Zaria same Northern Nigeria. It is said that Gowon chose the Military profession by prayer on the $21^{\text {st }}$ of December 1955 [11] He joined the Nigerian Army after Secondary education; attended military trainings in Ghana and England at various periods. His growth in the Army was gradual and he had opportunities to serve at Southern Cameroun and with the UN forces in the Congo at different times. He was a $\mathrm{Lt} \mathrm{Col}$ in the year 1964 same day with Ojukwu. Gowon was appointed the chief of Army staff by the Ironsi government after the $15^{\text {th }}$ January 1966 coup and later rose up to become the Head of State after the gruesome death of Maj Gen J T U Aguiyi Ironsi on the $29^{\text {th }}$ of July 1966. All through the war and till date, Gowon believes and says that he fought a war to unite Nigeria. He has never shifted from this stand.

\subsection{General Chukwuemeka Odumegwu Ojukwu}

ChukwuemekaOdumegwuOjukwuis exactly a sharp contrast of his opponent Gowon described above. Although he was equally born in the North, his father was a very wealthy Nigerian who hailed from the Eastern Nigeriaand, who already made a name throughout the length and breadth of Nigeria on $4^{\text {th }}$ November 1933 [11]. He had his Primary school education in Lagos, the then Nigerian capital and thereafter proceeded to England at the age of 13 to enroll in Epsom College. He later went to Lincoln Oxford and bagged his degree in History. He was highly educated before coming back to take the civil service job as an Administrative Assistant and, shortly joined the Nigerian Military. He was a very strong willed man. With quick promotions due to his previous academic experiences, he rose to the rank of Lt Col the same day with Gowon in 1964. He was in charge of $5^{\text {th }}$ battalion of the Nigerian Army in Kano at the time of the January 1966. He refused to accept the persuasions of Nzeogwu the leader of the coup but rather helped to stop the 1966 coup in the North just like Major J T U Aguiyi Ironsi did in Lagos. Ojukwu would always speak with disappointment over the rejection of the Aburi accord and states that that was the major reason he called for the Eastern Consultative Council which preferred to exist as a separate state. One thing led to another, and Nigeria declared war on the young state of Biafra.

Some Nigerians in fact, believe that a simple contrast of the two major Actors of the Nigerian -Biafran war, reveals a bit of personality clash of Gowon and Ojukwu. The later was very highly educated and exposed as well as of a wealthy background with so much confidence and strong will; while the former was of a relatively low background who might not have commanded a group more than 30 in number before becoming a head of state [11]. And both of them were promoted to the rank of $\mathrm{Lt} \mathrm{Col}$ the same day despite that one joined and trained in the Military far earlier but never got higher education. Ojukwu on the other hand already had a name locally in Nigeria and abroad by reason of his father's business fortune and by reason of his own earlier exposures.

\section{An Overview of the Civil War (1967-1970)}

Most persons from several quarters describe the Nigerian civil war as the most horrible war fought in the $20^{\text {th }}$ century. So many persons equally prefer to refer to the war simply as "the Biafran war" as we have explained elsewhere above. It was full of struggles on the part of the so-called Biafrans and bereft of mercy and justice on the part of the then Nigerian Military government. The war was declared, by the rest of Nigeria under the leadership of Lt Col. Yakubu Gowon against the people of the then Eastern Nigeria under the leadership of Lt Col. Chukwuemeka Odumegwu Ojukwu and was fought for thirty months non-stop.

The war presented a traumatic experience to Nigerians and Biafrans. Though the civil war ended forty-nine years ago, the memories of it, the stories, and its negative impacts on the socio-economic life of subsequent generationshave 
refusedto fade away. No matter the various reasons adduced by various scholars as to the actual causes of the NigeriaBiafra war, the finding of this paper is that the war was fought on the ground of two basic psycho-political instincts: (i) Ojukwu went to war on the basis of National security to protect the lives and property of the people of Eastern Nigeria who were hunted, harassed, pursued, and killed like animals all over Nigeria without protection from any quarters (be it police or the armed forces). This was equally the reason behind the declaration and the proclamation of the Republic of Biafra. Self preservation is the name of what Ojukwu did. (ii) Gowon on the other hand went to war to protect the Nigeria's sovereignty and territorial integrity [12]. It is thus proper therefore, to review, albeit consciously, the remote and immediate causes of the war.

\subsection{Remote Causes}

Although the wide spread killings and atrocities against the people of Eastern Nigeria in the North and other parts of Nigeria arose out of the disturbances which befell the Nigerian Federation in 1966 under the Military regime, as will be shown in this paper, the root causes of the disturbances antedated the military regime of Maj. Gen. J. T. U. Aguiyi Ironsi.

At the time of independence in October 1960, Nigeria was a federation of three unequal regions- the Northern, the Eastern, and the Western regions, plus the federal capital territory Lagos. The Northern region alone occupied about three quarters of the country's land mass. In fact, it was bigger than the other two regions combined. Moreover, according to the 1953 census, the Northern region contained slightly more than half of the Nigeria's population. This means that the North was more populous than the two southern regions put together [13]. This lopsided federal structure and the preponderance of the North, gave the Northerners an edge over other regions in political competition. It could dominate the country politically as long as its leaders wanted. While the Northern region surpassed the two Southern regions in population and land mass, the latter had by far more western educated people and was more economically advanced. Thousands of these educated and skilled Southerners settled in the North, where a large number of them were employees of the Northern government and its parastatals [13].

The march from colonialism to Independence was marked by absence of violence between the colonialists and the Nationalists. As independence approached, the North feared that the South will dominate the country's economy and bureaucracy with her teaming educated and skilled manpower. Hence, the North wanted the independence to be delayed until, in the words of Sir Abubakar Tafawa Balewa cited by Nnoli "we are ready for it" [14]. According to him, that was why when Anthony Enahoro of the Action Group (AG) moved his historic motion in March 1953 calling for independence in 1956, the North opposed it. Ahmadu Bello and the leaders of the Northern People's Congress (NPC) at that time proposed that 1956 be replaced with "as soon as practicable". The 1956 date, according to Ahmadu Below was not practicable.

It is important to note that the Northern fear of the Southern domination spurred its government to adopt what is still known as "Northernization policy", which was defined by the Northern Public Service Commission in 1957 as a system whereby "if a qualified Northerner is available, he is given priority in recruitment; if no Northerner is available, an expatriate may be recruited or a non-Northerner on contract terms" [13]. Northernization did not only affect the Southerners looking for jobs in the North. It also affected those already in the employ of the Northern regional government, most of who were subsequently retrenched. Between January 1954 and August 1958, a total of 2,148 Southerners lost their appointment with the Northern regional government [13].

Before January 1966, the position of Easterners in the North was unsecured. As far back as 1953, the Easterners in Kano were subjected to ruthless attack by the Northerners. This incidence was later to be known as the Kano riot of 1953. Hundreds of Easterners were killed and properties worth millions of naira were destroyed. The major reason for this planned attacks on an unsuspecting mainly Igbo people was that it was a retaliation for the booing and jeering experienced by the Northern members of parliament at the hands of Lagos crowds.

Soon after independence in 1960, Nigeria witnessed a series of social and political crises because the British left unresolved political problems, especially that of unity that were inherited by the Balewa government, which later generated into chaos and accounted for the collapse of the government. Sir Abubakar was handicapped by being the chosen lieutenant of Sir Ahmadu Bello- the Sadauna of Sokoto and Premier of Northern Nigeria, whose Northern Peoples' Congress (NPC) turned the majority in the House of Representatives. Sadauna was the real power behind the throne, at a time when the region was more powerful than the central government. Sir Abubakar's government collapsed as a result of his inability to deal effectively and decisively with the many crises of Nigeria's nationhood in the early years of independence. The political situation in the country reached its climax with the disputed census of 1962/63; and the political violence that marred the Western regional elections of 1965 which was counted as one of greatest discredits in the administration of Abubakar Balewa.

\subsection{Rise and Fall of Biafra}

Several persons have written treatises about the Biafran war. Madiebo Alexander [15], Achebe Chinua [16], etc., agree that the January and July 1966 coups led to each other due to the misunderstandings trailing in it. The January coup did not succeed in the East as much as it succeeded in the North where several government personnel lost their lives in the hand of the coup Actors thereby giving the wrong impression that the January coup was sectional and giving rise to a sectional counter-coup undertaken by the Military of Northern extraction and killing the then Head of State- Maj. 
Gen Ironsi gruesomely with no remorse.

When Lt Col. Yakubu Gowon emerged as the Head of State, the Governor of Eastern region, Lt Col Odumegwu Ojukwu refused to recognize him as a "legitimate" Head of State because of some reasons:

1. Gowon's counter coup and the massacre of Igbo military officers and civilians were seen by many as a revenge action against Ndi Igbo;

2. The continued and barbaric killings of Easterners especially Ndi Igbo in the North and other parts of Nigeria in the aftermath of Gowon's counter-coup had gone unabated and reached a genocidal proportion and no effort to stop them by Gowon and his fellow putschists;

3. As a result of the pogroms against Easterners in the Northern Nigeria in 1966/1967, the region faced a massive returnee problem. Easterners fled from their various places of abode in other parts of Nigeria and returned to their home region. A huge number of Easterners were involved in the enforced return home;

4. The trauma these killings left on the psyche of the Easterners convinced them more than anything else that they and especially, Ndi Igbo, were no longer welcome by the Hausa/Fulani in the Nigerian nation, and that only a separate existence could guarantee their continued safety and future;

5. There was a problem of legitimacy. The Northern junior military officers (Major T. Y Danjuma and Murtala Muhamed among others) who staged the counter coup insisted on producing the Head of State and imposed Gowon who was not a senior officer to Brigadier Ogundipe, Rear Admiral Wey, Col Adebayo, Lt Cols Ojukwu (then Military Governor of Eastern region), Imo, Effiong, Njoku among others;

6. The death of the Head of State, Maj Gen Ironsi had not been announced and as such, the seat was not vacant; and,

7. Tempers, bitterness, and mistrust among members of the federation were so high that the possibility of convening a meeting of provisional leaders was not feasible.

Following concerted efforts by people of good will from within and outside the country to resolve the impasse, Lt Gen Joseph Ankrah, the then Head of State of Ghana, arranged a Peace Summit in Aburi, Ghana on $4^{\text {th }}$ and $5^{\text {th }}$ January, 1967. Assured of his safety, Ojukwu travelled to Aburi and met with Gowon face to face since 29th of July 1966 Northern led counter coup d'etat. Apart from Gowon and Ojukwu, others who attended the meeting were the Military Governors of the North, West and Mid-West. Others included the Head of Navy, Military Administrator of Lagos, Inspector General of Police, and Deputy Inspector General of Police. The secretaries who went with them were: Permanent UnderSecretary, Federal cabinet office, Secretary to the Military Government, West, Secretary to the Military Government, East, Secretary to the Military Government, North, and, Under-Secretary, Military Governor's office, Mid-West. [17]
The Aburi meeting ended on $5^{\text {th }}$ January with some agreements which later became popularly known as "Aburi Accord". Back home, there arose sharp arguments on the various contradicting interpretations given to certain decisions reached at the Aburi Conference. While Ojukwu argued that they had agreed on confederal form of government, Gowon on the other hand claimed that the constitutional changes proposed by Ojukwu were unworkable and capable of breaking Nigeria.

The acrimonious disagreement over the Aburi Accord led to mounting tension between the Eastern region and the Federal government. By the end of March1967, Ojukwu announced his government's Edict, which empowered the Eastern region to take care of all Federal Government Parastatals, Statutory Corporations and Institutions in the East. In a fierce reaction, the Federal Government declared Ojukwu's pronouncement "illegal and unconstitutional". By April 4 1967, Nigerian Airways one of the Federal corporations taken over by the Eastern Government announced the suspension of flights between the Eastern region and other parts of the country. The Federal Government replied by blocking all Sea and Air ports in the East. Again, all postal services between the Eastern region and other parts of the Federation and oversea countries were suspended with immediate effect.

In a move to foster the threat of break-away of the Eastern region, the Federal Military Government on the $27^{\text {th }}$ of May, 1967 suddenly declared a state of emergency throughout Nigeria and promulgated decree No. 14, which divided the country into 12 states, 6 for the South and 6 for the North. As a result of this action which divided the Eastern region into three (East central, South central, and Rivers), and intended as a political master stroke to destroy the unity and solidarity of the Eastern region, Ojukwu immediately summoned an emergency meeting of the Eastern Nigeria Consultative Assembly. After two days of deliberation, the Assembly passed a resolution giving Ojukwu the mandate to declare the Eastern region "a sovereign state and independent Republic of Biafra". On May $30^{\text {th }} 1967$, Ojukwu addressed Ndi Igbo and the world to that effect.

The inability to stop the massacre of Ndi Igbo by the Gowon led Federal Government of Nigeria, and the rejection of Aburi Accord became highly frustrating and annoying. This made the Ojukwu led Eastern Region to choose secession as an alternative way to her freedom. That is why commenting on the creation of Biafra some months later, Ojukwu said:

“.... Worst of all came the genocide in which over 30,000 of our kids and kins were slaughtered in cold blood over Nigeria and nobody asked question, nobody showed regret, nobody showed remorse. Thus, Nigeria has become a jungle with no safety, no justice and no hope for our people. We decided there to found a new place, a human habitation away from the Nigerian jungle. That was the origin of our Biafra [18]".

The decision of Gowon to go back on agreement reached at Aburi actually led to the political decision to declare the 
state of Biafra by Ojukwu. The newly declared Republic of Biafra comprised of the present South Eastern states (Abia, Anambra, Enugu, Ebony, and Imo), the South South states of Akwa Ibom, Bayelsa, Cross River and Rivers, and Igbo areas of Delta state.

In reaction to the declaration of Biafra, the Federal Military Government on $6^{\text {th }}$ July 1967 , launched what they described as "Police Action" intended to discipline "Ojukwu and his clique" and end the rebellion in the East. The campaign was expected by the Federal Military Government to last a few weeks or a few months at most. Biafran resistance overwhelmed the Federal might that on August 26 1967, the Nigerian Military declared a total war against Biafra. That is how a thirty month nightmare and fratricidal war commenced, which claimed millions of lives, and caused untold sufferings and miseries to the Biafran people in general and children in particular.

Biafra secured some, albeit feeble, diplomatic support from Tanzania and Gabon, Ivory Coast, Zambia and Haiti. France and Portugal for the suffering Biafran population came from several charitable organizations such as the Caritas, International Red Cross, Joint Church Aids, and a member of national Red Cross organizations [17].

After three gruesome years of struggle for freedom for independence, Biafran resistance was broken and collapsed by the combination of the following strong and overwhelming external factors:

1. The Military might of the Federal Government;

2. The Military support given to the Federal Military by the World super powers especially USSR and USA;

3. Britain's Military and diplomatic support for Nigeria;

4. Active involvement of Egyptian and Sudanese fighterbomber pilots in the execution of the war and in favour of Nigeria;

5. Arab-Muslim world material, financial, moral, and economic support for Nigeria;

6. Land, air and sea blockade of Biafran territory; and,

7. Hunger and suffering on Biafrans.

It reached a time when the experiences of the war made some Biafrans seem downcast and demoralized. Food was very scarce andKwashiorkor had increased to a pandemic level. The Biafran currency was no longer of any use to anybody. The worst nightmare according to Mbachu [12] was between November and December 1969. Nigerian Army and Air force championed by the Soviet Union now intensified their indiscriminate shelling and bombing of Biafran villages with Russian- built Ilyushin bombers and MIG jet fighters. Finally, Ojukwu and his family escaped to Ivory Coast on the $9^{\text {th }}$ of January while his speech to end the war was broadcast on the $10^{\text {th }}$ January 1970 after General Ojukwu himself had left Biafra.

However the famous Ojukwu broadcast was coded enough for only the Military officers to understand that it meant the end of the 30 months war because there was great jubilation and relief all over the land. Many people thought that there was a major breakthrough, either at the war front or at the diplomatic level. Many even thought that France or the USA had finally given Biafra recognition as an Independent and Sovereign State. This after all was what everybody had waited for 30 months. Nevertheless, the Biafran Army commanders and officers could correctly read meanings into the speech and decipher the truth. The truth which was hard to bear was that Ojukwu had surrendered.

Then, the task of packaging the surrender speech more frankly was squarely left to Ojukwu's Chief of Staff Major Gen Philip Effiong to make. After thorough consultations with the top political advisers and Military Commanders, Major Gen Philip Effiong announced Biafran's surrender to the World at $4: 40 \mathrm{pm}$ on the $12^{\text {th }}$ of January 1970 in a radio broadcast.

\section{Some Failed Interventions of Third Parties}

The civil war did not begin and end without third parties interventions. Several third parties were involved. The most prominent among them included the General Ankra's initial Peace Talk at Aburi Ghana which almost succeeded. Ojukwu would later comment in his later years that none of those who attended the Aburi meeting with General Ankra - the Head of State ofGhana believed there was going to be any more problem as they all journeyed home peacefully and chatting together as brothers [19]. The Aburi meeting as already stated was held in what could be seen as the pre war days, and the full blown war began with the failure on the agreement reached at Aburi as the Peace Agreement Team reached Lagos.

Another party that intervened in the war was the OAU. The Organization of African Unity (OAU) madefiveattempts which failed basically because of the following reasons:

1. Both Gowon and Ojukwu insisted on status quo. As Gowon expected Ojukwu to drop arms and surrender, so did Ojukwu expect Gowon to remember the Aburi accord and resort to peace instead of giving him conditions.

2. Gowon had the backing of Britain which would not want its contraction Nigeria to fail and disintegrate.

3. Some African leaders were afraid to speak out straight against Lagos because there was this thought that, in the event of outright support of Biafra, most other tribes in the new African states were bound to follow suit as they were all contracted the same way with artificial boundaries.

4. Gowon was confident based on the international supports he got from super powers like Britain and USSR.

5. Gowon would not take any meeting of reconciliation serious unless it has to be for the surrender of Biafra. On one occasion, it was reported that while the meeting in Ethiopian capital was being held in the first week of August 1968, he was busy celebrating his marriage back there in Nigeria [17].

6. There were some Africans who opposed secession 
because they saw immense potential in Nigeria and hoped that Nigeria becomes a powerful and prestigious modern nation in Africa.

Moreover, there were some other interventionist actions detected from the activities of those five countries which decided and recognized Biafra. This decision by especially four of them was basically prompted by the refusal of the Federal Military Government of Nigeria to respond to the appeals to settle the conflict otherwise than by the force of arms. These were: Tanzania- $13^{\text {th }}$ April 1968; Gabon- $8^{\text {th }}$ May 1968; Ivory Coast- $14^{\text {th }}$ May 1968 ; and, Zambia- $30^{\text {th }}$ May 1968.

Despite all these interventions, the war fought until January 1970. As Uwechue puts it:

The collapse of Biafra put an end to the military aspect of the Nigerian drama. But the end of the war has not removed the cause of the conflict born of long standing political problems, the most acute among which was the question of security for the Ibos within the Nigerian federation. This socio-political problem remains to be solved. It is on the type of solution achieved that depends the political future of Nigeria [17].

Some questions about the 30 months Biafra war are still currently begging to be responded totill date. A few of them are:

1. Why was it necessary to declare a full blown war against a section of the country in order to unite Nigeria when there were many peaceful means to the so-called unity?

2. If the Federal government then fought a war to preserve nationhood, why is Nigeria still in partitions and hard to be one?

3. How did the Federal government of Nigeria handle end of "civil war", was there any meaningful reconciliation with or relegation of the region it fought?

4. Why are the Actors still justifying the course in the midst of so much looting which they promote and do in turns?

5. In the midst of several ongoing agitations by different tribes and regions, growing terrorism, obvious incompatibility of the federating units and a general break down of law and order, which way forward is the Nigerian leadership ready to adopt?

6. Summary/Conclusion

Let us summarize this work by suggesting that the 30 months war which was fought in Nigeria from 1967 to 1970 was not necessary at all because it was at most fought to promote selfish ambition of certain Actors in the political landscape of Nigeria. It was fought to idolize foreign influence and domination. It was fought to promote Neocolonialism. It was never fought to unite Nigeria as claimed by the Actors. Fani-Kayode, a Yoruba political activist in Nigeria has commented many years after the war that:

"if the Nigerian people really wanted their fortunes to change for the better and that if they really wanted to be restored to the great and prosperous nation and people that they once were, they needed to ask the Lord for forgiveness for what they did and what they were still doing to the Igbo nation. General Yakubu Gowon can conduct all the prayer sessions that he wants for Nigeria but until he acknowledges the fact that the genocide that the Igbo people were subjected to under his watch between 1966 and 1970 was unacceptable and until he appeals to the Igbo nation to forgive Nigeria for what we did to them, things will get from bad to worse. The shedding of innocent blood always results in divine retribution and it goes from generation to generation. Unless remorse is displayed, forgiveness sought and national repentance is established, the circle of divine retribution and judgment will continue unabated and affect the lives of millions. The civil war 'Gwodo-Gwodo' militias, made up of savage, bloodthirsty, heartless, godless, dark and evil men from Chad, Niger Republic, Mali and parts of North-Western Nigeria are the spiritual forefathers and the same dark forces that have resurrected as terrorist and killer herdsmen that are slaughtering our people ALL over the country today" [20].

The Actors' claim is that they fought for the unity of Nigeria. But, it is never generally agreed. Many rather believe that if unity was at the centre of their struggle, the war could not have been fought, and therefore the war has been seen as a mistake and not a justifiable action. Many equally believe that, the Aburi meeting was the best thing that ever happened in the history of Nigeria as at the first decade. The fact that the Aburi Accord was never implemented by the Gowon Military Government has been seen as a demonstration that something was seriously wrong somewhere among the then Military Government and the Actors beyond what they tell us. Instead of still claiming justified to have called external collaborators to come and help them kill their brothers amidst several pleas to stop, there should have been a true remorse capable of igniting forgiveness among all. Another reason why the claim to have fought for the unity Of Nigeria by the Actors of the war is contestable is that the after the war "3Rs" of Reconciliation, Rehabilitation, and Reconstruction, were never implemented either in full or honestly till date. Since the war ended, there has been rather unremorseful looting and corruption especially by the leadership of Nigeria, and most of them are the fighters of the civil war as observed by Akinkumi [11].

Indeed the war is not justifiable because it is misleading to justify it in view of the myriad of hypocrisy involved. For instance, during the course of the war, a lot of Biafrans proved scientifically and technologically useful. And after the end of the war, it could have been ideal to meaningfully engage such talents in the efforts of rebuilding the nation. This was not done. One of the reasons advanced by Reuben is psychological constraints. He said: The people were programmed to think and feel in a manner in consonance with the metropolis' ambitions and aspirations. There is no gainsaying that the predominant feeling in pre-civilwar Nigeria was that British values were incomparably superior to those of Nigeria [21].

Mbachu places his own as a recommendation when he 
opines that:

There is no way Nigeria can launch forward and remain afloat in this technologically sophisticated $21^{\text {st }}$ century without massive human resource development and research (including industrial espionage; if need be). The mistake of ignoring and missing the Biafran top and armament scientists who would have seriously quickened industrial development should never be allowed again. It is important to point out (especially to the Nigerian Military and para-military organizations) that Research is an essential military activity. Advances in military weaponry already demonstrates that [12].

In conclusion, we have established that, the war was fought for nothing. The Actors of the war cannot justify themselves, their actions and inactions in the war. Nigeria is fighting and is not united yet. The Nigerian environment seems hotter and even more delicate today than those dark beginning times. Every war which ends in a round table discussion produces both forgiveness and lasting strategies for peace and unity. Rwanda is a living instance. The functions and impacts of the UN is another pointer to this stand. In the case of Nigeria, several blunders were committed and are still going on. And the worst is the continual marginalization of the conquered Biafra and the raking of National economy by the so-called Actors, simply for the claim that they fought to unite the nation; a claim that has obviously been faulted by this paper.

In this concluding part, it could be truly nice to consider the opinion of Forsyth on the question, 'how do you view Nigeria? [22] Nigeria is, without exaggeration, the one true giant of Africa. Her people constitute nearly one half of the black people of the continent and two in five of all black people in the world. The resources concentrated within her borders would be the envy of most countries in Europe and the Americas. Her land mass is huge, her climate largely benign. All these should have made her not only the most powerful country in the black world, but among the dozen most powerful nations on the globe. Alas, it has not.

In view of the foregoing, we are right to suggest that, unless Nigeria achieves a peaceful marriage of her more than 250 ethnic groups brought together by Britain; unless Nigeria evolves a leadership which is truly free and enlightened- free from the fetters of recent history, enlightened by a keen perception of the true aspirations of its own people; unless Nigeria organizes herself in the fear of God and stops this jingoistic displays of make-believe shows, Nigeria is doomed by its own merits.

\section{References}

[1] Elagbulam, C., Interview with EmekaOjukwu on African Affairs, Washington DC. Nigeriatvonline.com 2002.
[2] Most or all of the Actors from the Nigeria side believe and claim tohave fought for the unity of Nigeria.

[3] Nwankwo, A. A., Nigeria: the challenge of Biafra, London, Rex Collins ltd 1981, P. 109.

[4] Peter, A. A. "Things we need to know about the Nigerian Civil War" www.books-written-about-Nigerian-civil-war. Accessed $15^{\text {th }}$ November 2019.

[5] www.african historian.com Accessed $16^{\text {th }}$ November 2019.

[6] www.en.wikipadia. Accessed $16^{\text {th }}$ November 2019.

[7] Okoro, I. A., "The problem of youth unemployment and restiveness in Kaduna South L G A of Kaduna state Nigeria", NDA Kaduna, A MIASS thesis November 2013, P. 8.

[8] Tediheke, M., NDA Kaduna, MIASS lecture discussion, 2013.

[9] Study mode.com/social conflict theory accessed $16^{\text {th }}$ November 2019.

[10] Nwobosi, E. N., "1966: The Dark truth", A Documentary, 19th January 2019, Accessed on 30th January 2019.

[11] Akinwunmi, A., "Hubris: a brief History of Nigeria", A Documentary in, OlakunleKasumu, Channels Club @ Channelstv.com. Accessed March 2, 2019.

[12] Mbachu, O., "Operations Research and Biafran Scientists: A study in Defence and National Security", Kaduna Medusa Academic Publishers 2009. P. 21.

[13] Iro, M. I.,"The population Census of Nigeria since Colonial times", Okigwe, 1987 chapter 4.

[14] Nnoli, O., "Ethnic politics in Nigeria" Enugu, Forth Dimension, 1978. Pp. 193-195.

[15] Madiebo, A., "The Biafran Revolution and The Nigerian Civil War" Enugu, ForthDeminsion, 1980.

[16] Achebe, C., "There was a Country: a personal history of Biafra" USA, The Penguin Press, 2012.

[17] Uwechue, R., "Reflections on the Nigerian Civil War: facing the future", New York, African Publishing corporation, 2003, Pp 14, 173.

[18] Ojukwu, C. O. "The Ahiara Declaration, the principles of the Biafran revolution” Geneva Switzerland, Mark Press 1969.

[19] Ukpabi, S., "The Aburi Conference: An Interview with Emeka Ojukwu", An NTA Documentary. Accessed $3^{\text {rd }}$ August, 2019.

[20] Kayode, F. F., "Gowon Must Beg Igbo For Civil War Genocide", Naira land forum, 22nd October, 2017.

[21] Ogbudinkpa, R. N., "The Economics of the Nigerian Civil War and Its Prospects for National Development" Enugu, Forth Dimension Publishing Company limited, 1985, P90.

[22] Forsyth, F., "Emeka”, Ibadan, Spectrum books limited, 2003, pp 132-133. 